\title{
Drought Index Analizes With Rainfall Patern Indicators Use SPI Method (Case Study Bangga Watershed)
}

\author{
Beti Mayasari ${ }^{1}$, I Wayan Sutapa ${ }^{2}$, Andi Rusdin ${ }^{3}$ \\ ${ }^{1}$ Program Master Civil Engineering, University of Tadulako, Palu, Central Sulawesi, Indonesia \\ ${ }^{2,3}$ Department of Civil Engineering, University of Tadulako, Palu, Central Sulawesi, Indonesia
}

\begin{abstract}
Irregular weather and climate changes caused by $\mathrm{El}$ - Nino effect drought in some areas, including in Indonesia. The location of this study lies in the Bangga watershed. The purpose of this study was to determine rainfall patterns, drought level, the worst drought that occurred and the prediction for the future. One method for analysis of drought is using SPI (Standardized Precipitation Index). This method aims to calculate the value of a drought index that would indicate the level of the existing drought in a region. Data used are monthly rainfall from two station for 23 years (year 1993-2015). After analyzing the drought, the projection made with software Makesens 1.0. The study results showed that the worst drought in Bangga watershed occurred in April 2015 with drought index -3516 for one monthly SPI, -2815 for three monthly SPI, -3254 for six monthly SPI, -2171 for nine monthly SPI, and - 2922 for twelve 12 monthly SPI. Once projected until 2050, generally Bangga watershed experiencing dry conditions with the worst drought in July with a value of -3.83 for one monthly SPI, -3.65 for three monthly SPI, -3.44 for six monthly SPI, -2.6 for nine monthly SPI and -2.32 for twelve monthly SPI.
\end{abstract}

Keywords: Standardized Precipitation Index (SPI), Drought Level Index, Makesens 1.0.

\section{INTRUDUCTION}

Irregular climate and weather changes give much impact to life. Climate change causing unbalanced between wet and dry season. The El Nino Phenomenon causes long dry season, the water availability is reduced and cause drought. $\mathrm{La}-$ Nina is a natural Phenomenon where the wet season becomes longer, and excessive rainfall resulted in the availability of abundant water that can cause flooding.

The El - Nino Phenomenon in Indonesia caused drought in some areas, and should not be seen as a minor problem because drought have been a threat that often disrupt agricultural production systems [1]. El - Nino also ever effect extensive forest fire in Indonesia.

Geographically, Indonesia is a maritime continent which resulted not all part of its region affected by El - Nino. In some regions, particularly in Central Sulawesi, El - Nino that occurred in 2015 generally have no drought potential or prolonged heat but it cause decreased and temperature increased and Even Discharge of water in some rivers also decreased, paddy fields still can be irrigated by using a rotational system. Although the impact only occurred in some areas and not signifant, but El - Nino must be alert causes drought in years- incoming years and prejudicial to human life. earliest signs of drought is the reduction precipitation under the normal conditions, then with the reduced supply of water in the storage The earliest signs of drought is the reduction precipitation under the normal conditions, then with the reduced supply of water in the storage reservoir or river as well as the Watershed which is a unity with the river and tributaries. Central Sulawesi has a lot of river basin areas spread across several river basin with different characteristics. One is the Bangga Watershed which is include in the basin Palu - Lariang.

Bangga Watershed is located at the west of Palu River and above the Bangga village consist of the mountain, hills and plains that have a large area and tends to tropical weather so its vulnerable to the drought phenomenon that could affect the water availability and social economic impact to all people who lives in this area. Therefore, it is necesarry to make a study to detect a drought level in Bangga Watershed and predict a drought that could prevail in coming years also use as an early warning system of drought

There are many methods of drought analysis, and in this research is used Standarized Precipitation Index (SPI) with rainfall patern indicators which is more flexible and simple to use than the other methods. This method is a model to measuring rainfall deficit at different time periods based on normal conditions. The drought that used in this methods is a meteorogical drought that occurred based normal condition in a season. 
The aim of this research are :

1. To determine the pattern of rainfall patern in the Bangga Watershed

2. To determine the drought index at Bangga Watershed in year 1993 to year 2015

3. To determine the drought level index and the worst drought that occurred in Bangga Watershed

4. To predict the drought that might occur in year 2020, year 2030 and year 2050

\subsection{Drought Definition}

\section{STUDY LITERATURE}

Various definitions of drought have been put forward by the other researchers such us [2], drought is deficiency of rainfall in a long period, and that cause bad impact on vegetation, animals and humans. Drought is also closely related to the reduction in rainfall, air temperature is above normal, low soil moisture and surface water supplies are insufficient. Drought can be defined with very little rainfall in a very long period of time so it cause a material adverse effect on living creatures, especially in fulfilling the needs of water for various purposes.

Drought can be categorized into four types: meteorologists drought, hydrological drought, agricultural drought, and socioeconomic drought [2] 1) Meteorologists drought is defined as the lack of normal rain or expected for a certain period of time

2) Hydrological drought is defined as a lack of surface water and groundwater supply in the lake and reservoirs, streams and groundwater levels.

3) Agricultural drought occur after meteorologists drought. This dryness associated with reduced water content in the soil (soil moisture) so it is not nearly enough to meet the water needs of crops.

4) Socio-Economic drought associated with a reduced supply of economically valuable commodity than normal as a result of drought meteorologists, agricultural and hydrological.

\subsection{Drought Index analyzes}

Drought meteorological constitute early indication of the drought, so it is necessary to do an analysis to determine drought level. The results of this analysis can be used as an early warning of impending drought farther [3].

The kinds of drought index analyzes that have been done are as below :

\section{Decile}

According [4], decile (D) is the point, score or value that divides the entire frequency distribution of the data that investigated into 10 parts each of $1 / 10 \mathrm{~N}$. Another definitions, decile defined as a point that limits to $10 \%$ the lowest frequency in the distribution. The third decile is a point that limits to $30 \%$ the lowest frequency in the distribution.

\section{Palmer Drought Severity Index}

Palmer drought index method uses the concept of water balance. Palmer's analysis uses two layers consist of soil top layer and bottom layer. Input data in this method are rainfall, soil water capacity and potential evapotranspiration. Potential evapotranspiration suspected of average temperature - to the Thornthwaite method. The advantages of this method in addition to generating the index value, the coefficient also climate parameters, namely evapotranspiration coefficient, coefficient of recharge, runoff coefficient (run off) and the coefficient of soil moisture loss. In this analysis, drought index classification is divided into 11 classes with an index of zero as a normal state[5].

\section{Standardized Precipitation Index}

Standardized Precipitataion index (SPI) methods is an index that used to determine deviations of the normal precipitation in a long period (monthly, bimonthly, quarterly, and so on). Where if rain after shrinking will lead to the reduced of water content in the soil and flow rate [6].

\section{Theory of Run}

This method was first developed by Yjevich in August 1967. In 2014 the Ministry of Public Works make the mannual drought index calculation use method run. This method aims to calculate drought indices as the duration of the drought, the longest and largest number of drought on scattered location of station in a region. Theory of run was a comparative between Long and the amount of water deficit. The calculations Priciples of this methods were follow a process variable date [3].

\subsection{Standardized Precipitation Index Methods}

SPI is designed to measure a deficit of precipitation in some span of time. This timescale reflects the impact of drought on water resources of different required by the various decision-makers. Meteorological and soil moisture conditions (agriculture) respond to precipitation anomalies on a relatively short span of time, for example 1 to 6 months, while discharge rivers, reservoirs, and groundwater responds to a long-term precipitation anomalies of the order of six months to twenty-four months or more, SPI one month to six months for the agricultural drought, and SPI six months to twenty-four months or more for hydrological drought analysis and application [7]. In the calculation of Standardized Precipitation Index (SPI) for a location, required monthly precipitation data with a sufficiently long period of time. Ideally, 
the data needed at least 20-30 years of monthly values, with optimal data 50-60 years or more [7]. Because of time series needed for the calculation of the SPI is quite long, so to match the time series precipitation data as climatology, the gamma distribution was selected. This distribution is defined on the frequency or probability density function [8].

$\mathrm{G}(\mathrm{x})=\int g(x) d x=1 \beta \alpha \Gamma(\alpha) \int t \alpha-1 e-x / \beta d x x 0 x 0$

Equation(2.1) for $\mathrm{x}>0$, where

$\alpha>0$, is the shape parameter

$\beta>0$, is the scale parameter

$\mathrm{x}>0$, is the amount of Precipitation

$\Gamma(\alpha)=\int y \alpha-1 e-y d y \infty 0$

$\Gamma(\alpha)=$ a gamma function

SPI calculation includes matching the gamma probability density function against frequency distribution from the the amount of precipitation for each station. $\alpha$ and $\beta$ were estimated for each rainfall station by using the following formula:

$\Gamma(\alpha)=$ a gamma function

$\alpha=14(1+\sqrt{1+4 A 3})$

$\mathrm{A}=\ln (\mathrm{xr})-\sum \ln (x) / n$

or

$$
\alpha=\frac{x r^{2}}{s^{2}}
$$

$\beta=\underline{x r}$

For $\mathrm{x}>0$ Where,

$\mathrm{n}=$ number of observations of precipitation

$\mathrm{xr}=$ precipitation average

$\mathrm{x}=$ the amount of precipitation

Because of the gamma function is undefined for $\mathrm{x}=$ 0 , whereas the distribution of precipitation likelihood consists from the zero value, then the cumulative probability becomes:

$H(x)=q+(1-q) \cdot G(x)$

Where $\mathrm{q}$ is the probability of zero.

If $\mathrm{m}$ is the number of zeros from the the entire time series, then $\mathrm{q}$ can be estimated by $\mathrm{m} / \mathrm{n}$. Cumulative probability $\mathrm{H}(\mathrm{x})$ is then transformed into a normal standard with average (mean) of 0 and a difference of 1 , or using the following formula:

The calculation of $\mathrm{Z}$ or SPI for $0<\mathrm{H}(\mathrm{x}) \leq 0.5$

$$
Z=-\left[\mathrm{t}-\frac{\mathrm{C}_{0}+\mathrm{C}_{1} \cdot \mathrm{t}+\mathrm{c}_{2} \cdot \mathrm{t}^{2}}{1+\mathrm{d}_{1} \cdot \mathrm{t}+\mathrm{d}_{2} \cdot \mathrm{t}^{2}+\mathrm{d}_{3} \cdot \mathrm{t}^{3}}\right]
$$

With,

$\left.\mathrm{t}=\mathrm{V} \operatorname{Ln}(1 / \mathrm{h}(\mathrm{x}))^{2}\right)$

the calculation of $\mathrm{Z}$ or SPI for $0,5<\mathrm{H}(\mathrm{x}) \leq 1,0$

$(2.1 \bar{\theta})=+\left[t-\frac{c_{0}+c_{1} \cdot t+c_{2} \cdot t^{2}}{1+d_{1} \cdot t+d_{2} \cdot t^{2}+d_{3} \cdot t^{3}}\right]$
With,

$$
\mathrm{t}=\mathrm{V} \operatorname{Ln}\left(1 /\left(1-(\mathrm{h}(\mathrm{x}))^{2}\right)\right.
$$

where :

$\mathrm{c} 0=2,515517, \mathrm{~d} 1=1,432788$

$\mathrm{c} 1=0,802853, \mathrm{~d} 2=0,189269$

$\mathrm{c} 2=0,010328, \mathrm{~d} 3=0,001308$

The values of $\mathrm{c} 0, \mathrm{c} 1, \mathrm{c} 2, \mathrm{~d} 1, \mathrm{~d} 2, \mathrm{~d} 3$ given in the above equation, is widely used for constant SPI [8]. Drought acuity index based on SPI which is an analog sharpness SPI drought by SPI values can be seen in the following table.

Table. 1. Drought level based on SPI Value

\begin{tabular}{|c|c|}
\hline SPI Values & Classification \\
\hline 2.00 & Extremely wet \\
$1.5-1.99$ & Very wet \\
$1.00-1.49$ & Moderately wet \\
$-0.99-0.99$ & Near nomal \\
$-1.00-1.49$ & Moderately dry \\
$-1.5-1.99$ & Severely dry \\
$-2.0-<-2.00$ & Extremely dry \\
\hline
\end{tabular}

2.3 Mann Kendall - Sen's Methods (Makesens) Mann - Kendall test Methods is used to evaluate whether there is a tendency in the data span of hydrology [9]. Using the Mann Kendall Test to assess their tendency to rain. According [10], Mann Kendall calculation is as follows:

$\mathrm{S}=\sum_{k=1}^{n-1} \sum_{j=k+1}^{n} \operatorname{sign}\left(X_{j}-X_{k}\right)$

$\sigma \mathrm{s}=\sqrt{n(n-1)(2 n+5) / 18}$

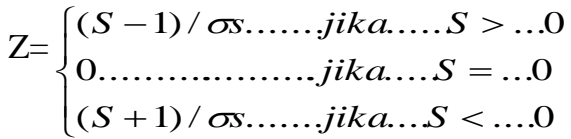

Where: $\mathrm{Xj}$ and $\mathrm{Xk}$ is data value " $\mathrm{j}$ " and " $\mathrm{k}, \mathrm{j}>\mathrm{k}$ $\sigma \mathrm{s}=$ variant

$\mathrm{n}=$ number of data

After the Mann-Kendall test ,to predict the future use non-parametric Sen'S methods. Both methods are combined so-called Makesens method.

\section{RESEARCH METHODS}

The location of this research is the Bangga Watershed and was a Miu sub watershed that located on the western Palu river and above the Bangga village composed of mountains and hills. administratively, its located in the district of South Dolo, Sigi Central Sulawesi. Bangga Watershed geographically located at $01^{\circ} 14^{\prime} 00$ " South Hemisphere and 119 $55^{\prime} 30^{\prime \prime}$ East Hemisphere. 
Bangga watershed drainage area of $69.04 \mathrm{~km}^{2}$. The Location study can be seen in the map below:
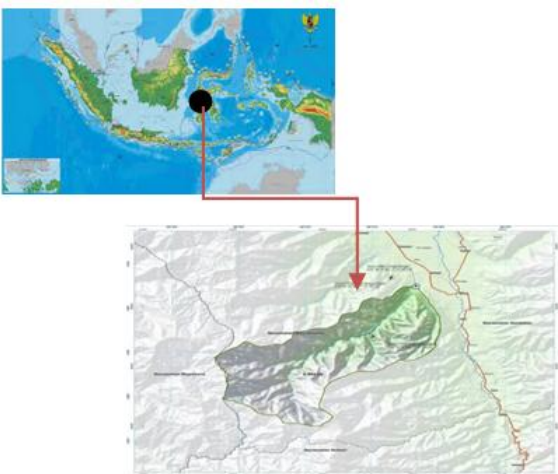

Figure 1. Location of research

The data used in this research are secondary data from Bangga Top and Bottom station consisting of a topographic map and precipitation data (year 1993 till year 2015). To complete this study can be carried out the following stages:

a. Calculate the value of a drought index by using SPI

b. Calculate the value of the parameter Sens using Mann Kendall Model

c. After obtaining the parameter sens, made projections to forecast drought in year 2020, year 2030 and year 2050 .

\section{RESULT AND DISCUSSION} 4.1 SPI Drought Index

To find an area experiencing climate change such as drought in Bangga Watershed, it is necessary to seek a drought index first. In this study using SPI (Standardized Specification Index) methods for one month, three months, six months, nine months and twelve months periods. The recapitulation for one month SPI is described in Table 1.

Table.1 Recapitulation of 1monthly SPI Index Value

\begin{tabular}{|c|c|c|c|c|c|c|c|c|c|c|c|c|c|c|c|c|c|c|c|c|c|c|c|}
\hline \multirow{2}{*}{ Num } & \multirow{2}{*}{ Year } & \multicolumn{2}{|l|}{ January } & \multicolumn{2}{|c|}{ Pebruary } & \multicolumn{2}{|l|}{ March } & \multirow{2}{*}{\begin{tabular}{|c|} 
April \\
SPI Value DL \\
\end{tabular}} & \multirow{2}{*}{\begin{tabular}{|c|c|}
\multicolumn{2}{c}{ May } \\
SPI Value & DL
\end{tabular}} & \multicolumn{2}{|l|}{ Jume } & \multicolumn{2}{|l|}{ July } & \multicolumn{2}{|l|}{ Augut } & \multicolumn{2}{|l|}{ September } & \multicolumn{2}{|l|}{ Oktober } & \multicolumn{2}{|l|}{ Norember } & \multicolumn{2}{|c|}{ December } \\
\hline & & SPI Value & DL & SPI Value & $\mathrm{DL}$ & SPI Value & DL & & & SPI Value & $\mathrm{DL}$ & SPIV alue & DL & SPIVahe & $\mathrm{DL}$ & SPIVatue & & SPIV Value & DL & SPI Value & DL & SPI Value & DL \\
\hline 1 & 1993 & -2.357 & $\mathrm{BD}$ & -1.712 & $E D$ & -1.712 & $S D$ & $-1.712 \mathrm{SD}$ & $-1.359 \mid S D$ & -0.613 & & 1.901 & ww & -0.012 & $\mathrm{NN}$ & 0.311 & & 0.983 & $\mathrm{NN}$ & 0.898 & $\mathrm{~N}$ & 0.766 & $\mathrm{NN}$ \\
\hline 4 & 96 & 1.024 & $\mathrm{MW}$ & & $\mathrm{NN}$ & 24 & $\mathrm{NN}$ & $70 \mathrm{NN}$ & $0.657 \times \mathbb{N}$ & .930 & $\mathrm{NN}$ & 0.220 & $\mathrm{NN}$ & .035 & $\mathrm{MW}$ & 1.019 & MWI & 0.752 & $\mathrm{NN}$ & 323 & $\mathrm{NN}$ & 282 & $\mathrm{NN}$ \\
\hline 5 & y & 372 & $\mathrm{NN}$ & & $\mathrm{NN}$ & & $\mathrm{NN}$ & $44 \mathrm{MN}$ & $.906 \mathrm{NN}$ & 628 & $\mathrm{NN}$ & 1.116 & Mix & 249 & $E D$ & -1.920 & SD & -1.400 & $\mathrm{MD}$ & 805 & MN & 0.071 & $\mathrm{NN}$ \\
\hline 6 & 1998 & 226 & SD & & $\mathrm{NN}$ & 44 & $\mathrm{NN}$ & $68 \mathrm{MW}$ & $.021 \mathrm{NN}$ & -0.601 & $\mathrm{NN}$ & 1.952 & ww & .043 & $\mathrm{NN}$ & 888 & $\mathrm{~N}$ & .023 & $\mathrm{NN}$ & 1210 & $\mathrm{MD}$ & 0.908 & $\mathrm{NN}$ \\
\hline 9 & 20 & 987 & $\mathrm{NN}$ & 024 & $\mathrm{MD}$ & -0.004 & $\mathrm{NN}$ & $32 \mathrm{NN}$ & $0.429 \Omega$ & -0.293 & $\mathrm{NN}$ & -1.249 & An: & -1.594 & $S D$ & 0.206 & $\mathrm{NN}$ & -0.091 & $\mathrm{NN}$ & 1934 & SD & 0.144 & 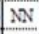 \\
\hline 10 & 20 & & $\mathrm{NN}$ & 604 & NN & -2.263 & ED & SD & \begin{tabular}{|c|c|}
589 \\
\end{tabular} & -1.346 & $\mathrm{MD}$ & 0.192 & $\mathrm{NN}$ & 216 & $\mathrm{MD}$ & 0.447 & $\mathrm{NN}$ & -0.340 & $\mathrm{NN}$ & $064:$ & MN & 255 & N3 \\
\hline 11 & 20 & 873 & $\mathrm{NN}$ & 856 & NN & 0.241 & $\mathrm{NN}$ & $75 \mathrm{NN}$ & $0.122 \Omega$ & -1.264 & $\mathrm{MD}$ & -0.288 & $\mathrm{NN}$ & .097 & $\mathrm{NN}$ & -1.250 & MD & 0.911 & $\mathrm{NN}$ & 0.105 & $\mathrm{NN}$ & -0.655 & NN \\
\hline 12 & 04 & & $\mathrm{NN}$ & 020 & $\mathrm{MD}$ & & $\mathrm{NN}$ & $18 \mathrm{NN}$ & $0.746 \mathrm{NN}$ & -0.853 & $\mathrm{NN}$ & 0.356 & $\mathrm{~N}$ & 304 & $B D$ & -0.060 & $\mathrm{NN}$ & -1.701 & $S D$ & -1275 & $\mathrm{MD}$ & -1.239 & $M$ \\
\hline 13 & 05 & 381. & MD & 603 & $\mathrm{NN}$ & 0.552 & NN & $058 \mathrm{NN}$ & $0.253 \times \mathrm{N}$ & -1.092 & MID & -0.225 & $\mathrm{NN}$ & .038 & $\mathrm{NN}$ & 578 & $\mathrm{NN}$ & 0.915 & $\mathrm{NN}$ & -0909 & $\mathrm{NN}$ & 0.198 & $\mathrm{NN}$ \\
\hline 14 & & & $\mathrm{NN}$ & & $\mathrm{NN}$ & .445 & $\mathrm{MD}$ & $43 \mathrm{NN}$ & $.024 \mathrm{~N}$ & -0.731 & $\mathrm{NN}$ & 0.313 & $\mathrm{NN}$ & 264 & $\mathrm{NN}$ & 122. & $\mathrm{NN}$ & -2.293 & $\mathrm{ED}$ & -0.035 & $\mathrm{NN}$ & .325 & N \\
\hline 20 & & & $\mathrm{NN}$ & & NN & -0.792 & $\mathrm{NN}$ & $2 \mathrm{NN}$ & $-1.109 / \mathrm{MD}$ & -0.279 & $\mathrm{NN}$ & -1.071 & $\mathrm{MD}$ & 490 & $\mathrm{NN}$ & -0.280 & $\mathrm{NN}$ & 0.568 & $\mathrm{NN}$ & 1.553 & MW & 2.274 & 21 \\
\hline 21 & & & $\mathrm{NN}$ & & NN & & $\mathrm{NN}$ & $99 \mathrm{NN}$ & $0.285] \mathrm{NN}$ & -0.375 & $\mathrm{~N}$ & 0.740 & N & 087. & $\mathrm{NN}$ & $1.282 \mathrm{f}$ & and & 0.601 & $\mathrm{NN}$ & 272 & $\mathrm{NN}$ & .121 & M \\
\hline 22 & 2014 & 0.099 & $\mathrm{NN}$ & -0.228 & NN & 0.079 & $\mathrm{NN}$ & $-1.240 \mathrm{MD}$ & $1.706 \mathrm{WW}$ & -0.707 & NN & -0.405 & $\mathrm{NN}$ & -0.232 & $\mathrm{MN}$ & -2.062 & $\mathrm{BD}$ & -1.400 & $\mathrm{MD}$ & .0994 & $\mathrm{NN}$ & 0.361 & $\mathrm{NS}$ \\
\hline 23 & 2015 & -2.357 & BD & -1.712 & $S D$ & -1.054 & $\mathrm{MD}$ & $-3.516 \mathrm{ED}$ & $-1.066 \mid \mathrm{MD}$ & -1.296 & $\mathrm{MD}$ & -1.587 & SD & -2.315 & BD & 0.112 & $\mathrm{NN}$ & $-0,773$ & $\mathrm{NN}$ & -0.013 & $\mathrm{NN}$ & -1.97 & SD \\
\hline
\end{tabular}

Tabel 2. Recapitulation of 3 monthly SPI Index Value

\begin{tabular}{|c|c|c|c|c|c|c|c|c|c|}
\hline \multirow{2}{*}{ Num } & \multirow{2}{*}{ Year } & \multicolumn{2}{|c|}{ Jan-March } & \multicolumn{2}{|c|}{ April-June } & \multicolumn{2}{|c|}{ July - Sept } & \multicolumn{2}{|c|}{ Old - Dec } \\
\hline & & SPI Value & DL & SPI Value & DL & SPI Value & DL & SPI Value & TK \\
\hline 1 & 2 & 3 & & 4 & & 5 & & & \\
\hline 1 & 1993 & -1.712 & SD & -1.434 & $\mathrm{MD}$ & 1.052 & MW & 1.084 & MWV \\
\hline 2 & 1994 & 1.783 & VW & 2.287 & EW & 0.350 & NN & 1289 & MV \\
\hline 3 & 1995 & 2.104 & EW & 0.752 & $\mathrm{NON}$ & 2.171 & EW & 1243 & $\mathrm{MWV}$ \\
\hline 4 & 1996 & 1.263 & MN & 1.077 & MN & 0.963 & NN & -0.080 & $M D$ \\
\hline 5 & 1997 & 0.353 & NNN & -0.312 & NN & -0.628 & NN & 0.716 & NN \\
\hline 6 & 1998 & -0.718 & NON & 0.626 & NDN & 1.315 & MN & $-1.113 \mid$ & MD \\
\hline 7 & 1999 & -0.772 & NON & -0.428 & NN & -0.025 & NN & -0.413 & NN \\
\hline 8 & 2000 & 0.491 & $\mathrm{NN}$ & 0.549 & $\mathrm{NN}$ & -0.266 & $\mathrm{NN}$ & -0.421 & NN \\
\hline 9 & 2001 & 0.282 & NN & 0.593 & NN & -1.201 & $M D$ & -1.100 & $\mathrm{MD}$ \\
\hline 10 & 2002 & -0.720 & $\mathrm{NNN}$ & -0.425 & $\mathrm{NNN}$ & -0.328 & $\mathrm{NN}$ & 0.497 & NNN \\
\hline 11 & 2003 & -0.019 & NN & -0.155 & NN & -0.822 & NN & -0.115 & NN \\
\hline 12 & 2004 & -0.276 & NN & 0.187 & NN & -0.713 & NN & -2.101 & ED \\
\hline 13 & 2005 & -0.320 & $\mathrm{NN}$ & -0.519 & NN & -0.020 & $\mathrm{NN}$ & -0.202 & SD \\
\hline 14 & 2006 & -0.413 & NN & -0.168 & NN & -0.102 & NN & -0.599 & NN \\
\hline 15 & 2007 & 0.975 & $N \mathrm{~N}$ & 1.241 & MNV & 0.648 & $N \mathrm{~N}$ & 0551 & NN \\
\hline 16 & 2008 & 0.184 & NN & 0.788 & NN & -0.949 & NN & -1.049 & MD \\
\hline 17 & 2009 & -0.158 & NN & -0.603 & $\mathrm{NNN}$ & -0.664 & NN & 0532 & $\mathrm{NIN}$ \\
\hline 18 & 2010 & 0.270 & NN & -0.307 & NN & 1.306 & NW & $-0 \leq 41$ & NN \\
\hline 19 & 2011 & 0.236 & NN & -1.490 & $\mathrm{MD}$ & 0.554 & NN & 0.760 & NN \\
\hline 20 & 2012 & -0.230 & NN & -0.536 & NN & -0.367 & NN & 2.104 & $\mathrm{NNN}$ \\
\hline 21 & 2013 & 0.511 & NN & -0.728 & NN & 0.826 & NN & 0.783 & NN \\
\hline 22 & 2014 & -0.142 & $\mathrm{NN}$ & 0.613 & NN & -1.149 & MD & -0960 & NN \\
\hline 23 & 2015 & -2.192 & ED & -2.815 & ED & -1.498 & $\mathrm{MD}$ & -0.985 & NN \\
\hline
\end{tabular}


Table 3. Recapitulation of 6,9 , and 12 montly SPI index Value

\begin{tabular}{|c|c|c|c|c|c|c|c|c|c|}
\hline Num & Year & \multicolumn{4}{|c|}{6 Month SPI } & \multicolumn{2}{|c|}{$\begin{array}{c}\text { 9Month SPI } \\
\text { January - September }\end{array}$} & \multicolumn{2}{|c|}{$\begin{array}{c}12 \text { Month SPI } \\
\text { January - December }\end{array}$} \\
\hline 1 & 2 & 3 & & 4 & & \multicolumn{2}{|l|}{$\frac{\text { SPI Value }}{4}$} & \multicolumn{2}{|l|}{ (5) } \\
\hline 1 & 1993 & -2.494 & ED & 0.423 & NN & -1.230 & $\mathrm{MD}$ & -0.827 & NN \\
\hline 3 & 1995 & -0.042 & NN & 1.208 & MW & 1.327 & NN & 1.224 & MW \\
\hline 4 & 1996 & -0.495 & NN & -0.184 & NN & 0.521 & NN & 0.243 & NN \\
\hline 5 & 1997 & -0.618 & NN & -0.688 & NN & -0.943 & NN & -0.751 & NN \\
\hline 6 & 1998 & -0.671 & NN & -0.299 & NN & -0.179 & NN & -0.570 & NN \\
\hline 10 & 2002 & -1.273 & $\mathrm{MD}$ & -0.676 & NN & -1.315 & $\mathrm{MD}$ & -1.101 & $\mathrm{MD}$ \\
\hline 11 & 2003 & -0.773 & NN & -1.157 & $\mathrm{MD}$ & -1.126 & $\mathrm{MD}$ & -1.085 & $\mathrm{MD}$ \\
\hline 12 & 2004 & -0.732 & NN & -2.198 & ED & -1.059 & $\mathrm{MD}$ & -1.525 & SD \\
\hline 13 & 2005 & -1.124 & $\mathrm{MD}$ & -0.886 & NN & -1.082 & $\mathrm{MD}$ & -1.143 & $\mathrm{MD}$ \\
\hline 14 & 2006 & -0.989 & NN & -1.133 & $\mathrm{MD}$ & -1.024 & $\mathrm{MD}$ & -1.201 & $\mathrm{MD}$ \\
\hline 15 & 2007 & 0.483 & NN & -0.093 & NN & 0.329 & NN & 0.217 & NN \\
\hline 16 & 2008 & -0.185 & NN & -1.894 & SD & -0.688 & NN & -1.013 & MD \\
\hline 23 & 2015 & -3.254 & ED & -2.171 & ED & -3.113 & ED & -2.922 & ED \\
\hline
\end{tabular}

From the calculation of the SPI, the result that SPI drought index showing a tendency to dry and wet conditions in accordance with the value stated in the table level SPI drought. At SPI 1 Monthly, the index value of extreme drought or extremely dry in April 2015 with the index value 3516. This corresponds to the pattern of rainfall in the Bangga watershed of the month with the rainfall deficit. At the 3-monthly SPI index worst drought occurred in the period from April to June 2015 with the index value -2815 . Extremely wet in the period April to June 1994 index value of 2287. the SPI 6monthly, the index value indicates a severe drought that is in the period from January to June 2015 with the SPI value -3254. At SPI 9 monthly, the index value of the worst drought occurred in 2015 with a score of -3113 .

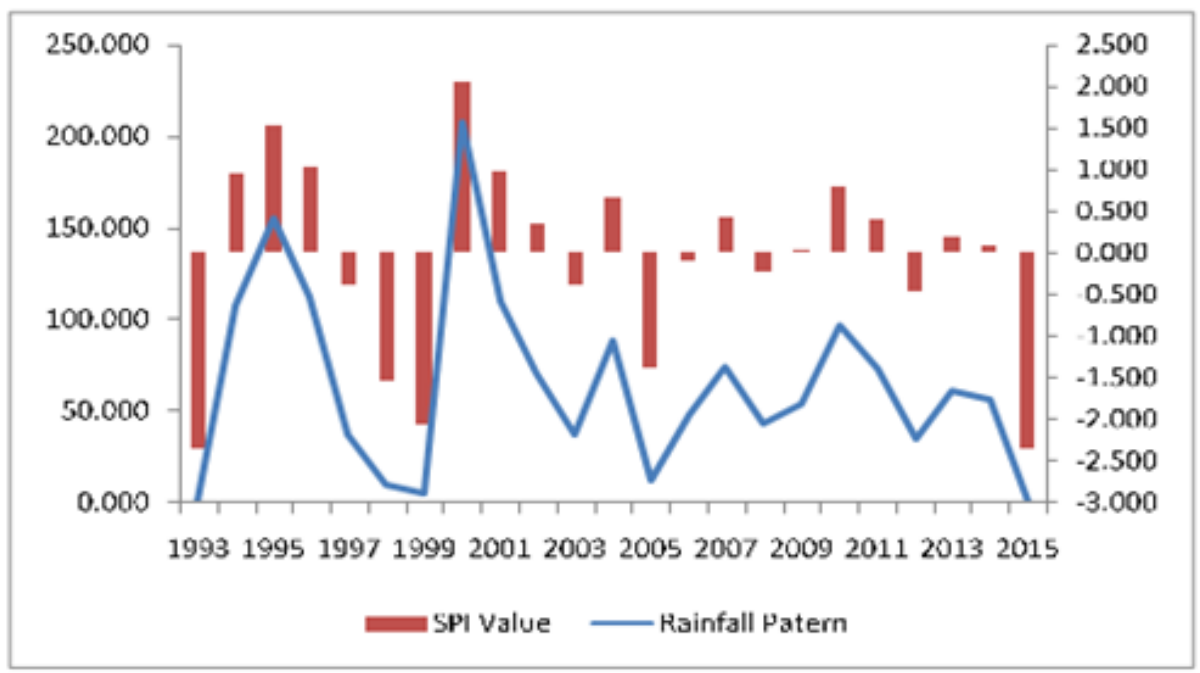

Figure.2 Relation between Rainfall Pattern and SPI Value

From the graph above, it can be seen the relationship between rainfall pattern with a drought index for one month, where in 1993, 1999 and 2015 rainfall patterns show a lack of rainfall in the Bangga watershed and SPI values shows the state extremely dry with the worst drought in 1993 and 2015. While high rainfall occurred in 1995, 1996 with the highest rainfall month of January in 2000 and SPI values indicate extremely wet conditions during the year. correspondence between rainfall patterns and the value of SPI also looks at SPI 1, 3, 6, 9 and 12 monthly.

To determine the drought projected in the future, the SPI index value needs to be analyzed first using the Mann-Kendall with the help of Software MAKESENS 1.0. Then to determine the prediction of drought used non-parametric methods Sens assuming a linear trend. The results of calculations are presented in the following table: 
Table. 4. Recapitulation of Sens Parameters

\begin{tabular}{|c|c|c|c|c|}
\hline \multirow{2}{*}{ Number } & \multirow{2}{*}{ SPI Periods } & \multicolumn{3}{|c|}{ Sens Parameter } \\
\hline & & $\mathbf{Q}$ & B & $\mathbf{Z}$ \\
\hline $\mathbf{I}$ & \multicolumn{4}{|l|}{1 Monthly SPI } \\
\hline 1 & January & -0.04 & 0.73 & -0.82 \\
\hline 2 & February & -0.02 & -0.40 & -0.50 \\
\hline 3 & March & -0.04 & 0.65 & -0.90 \\
\hline 4 & April & -0.04 & 0.94 & -1.61 \\
\hline 5 & May & -0.02 & 0.36 & -0.74 \\
\hline 6 & June & 0.01 & -0.97 & 0.63 \\
\hline 7 & July & -0.08 & 0.74 & -2.22 \\
\hline 8 & August & -0.01 & 0.09 & -0.32 \\
\hline 9 & September & -0.03 & 0.46 & -1.11 \\
\hline 10 & October & -0.06 & 0.64 & -2.25 \\
\hline 11 & November & -0.01 & 0.08 & -0.11 \\
\hline 12 & December & 0.05 & -0.42 & 1.16 \\
\hline II & \multicolumn{4}{|l|}{3 Monthly SPI } \\
\hline 1 & January - March & -0.03 & 0.47 & -0.85 \\
\hline 2 & April - June & -0.08 & 0.91 & -2.22 \\
\hline 3 & July - September & -0.06 & 0.41 & -1.85 \\
\hline 4 & October - December & -0.03 & 0.17 & -0.85 \\
\hline III & \multicolumn{4}{|l|}{6 Monthly SPI } \\
\hline 1 & January - June & -0.03 & -0.49 & -1.00 \\
\hline 2 & July- December & -0.06 & -0.16 & -1.27 \\
\hline IV & \multicolumn{4}{|l|}{9 Monthly SPI } \\
\hline 1 & January - September & -0.04 & -0.50 & -1.27 \\
\hline $\mathbf{V}$ & \multicolumn{4}{|l|}{12 Monthly SPI } \\
\hline 1 & January - December & -0.03 & -0.58 & -1.27 \\
\hline
\end{tabular}

To find out more projection Drought Index for 1 month, 3 months 6 months 9 monthsand 12-months, then made tables and graphs of historical data and projections. Examples projections are presented as follows:

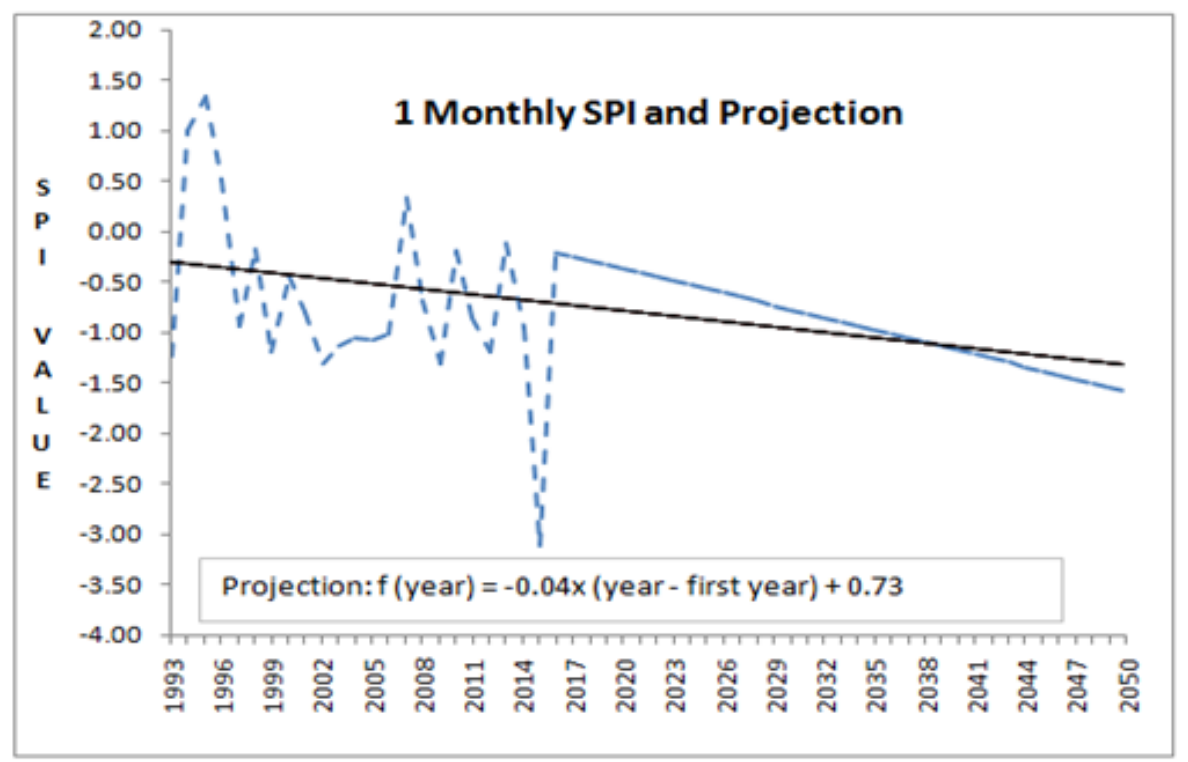

Figure 3. Sen's Projection in January for 1 Monthly SPI

The graph above shows that based on the historical data, 1-month SPI drought index in January has decreased every year but not significant, as in year 2020 with an index value of -0.37 with normal conditions, in year 2030 the index value of 0.77 with normal conditions and year 2050 with the value of the index -1.58 shows extremely dry conditions. Generaly 1-month SPI drought index decreased except in June and December which increased the index by 0:01 and 0:05 per year. 
Table .5. The equation of Sen's Projection

\begin{tabular}{|c|c|c|c|}
\hline Number & SPI Periods & Equation of Projection & $\begin{array}{c}\text { The A verage } \\
\text { Changes }\end{array}$ \\
\hline I & \multicolumn{3}{|l|}{1 Monthly SPI } \\
\hline 1 & January & $f($ year $)=-0,04 x$ (year - first year $)+0.73$ & 0.04 \\
\hline 2 & February & $f($ year $)=-0,02 \times$ (year - first year) -0.40 & 0.02 \\
\hline 3 & March & $f($ year $)=-0,04 x$ (year - first year) +0.65 & 0.04 \\
\hline 4 & April & $f($ year $)=-0,04 x$ (year - first year) +0.94 & 0.04 \\
\hline 5 & May & $f($ year $)=-0,02 \times$ (year - first year $)+0.36$ & 0.02 \\
\hline 6 & June & $f($ year $)=0.01 \times$ (year - first year $)-0.97$ & 0.01 \\
\hline 7 & July & $f($ year $)=-0,08 \times$ (year - fist year $)+0.74$ & 0.08 \\
\hline 8 & August & $f($ year $)=-0,01 \times$ (year - first year) +0.09 & 0.01 \\
\hline 9 & September & $f($ year $)=-0,03 x$ (year - fist year $)+0.46$ & 0.03 \\
\hline 10 & October & $f($ year $)=-0,06 x$ (year - fist year) +0.64 & 0.06 \\
\hline 11 & November & $f($ year $)=-0,01 \times$ (year - first year $) \div 0.08$ & 0.01 \\
\hline 12 & December & $f($ year $)=0,05 x$ (year - first year) -0.42 & 0.05 \\
\hline II & \multicolumn{3}{|l|}{3 Monthly SPI } \\
\hline 1 & January-March & $f($ year $)=-0,03 \times($ year - first year $)+0.47$ & 0.03 \\
\hline 2 & April - June & $f($ year $)=-0,08 \times$ (year - first year $)+0.91$ & 0.08 \\
\hline 3 & July - September & $f($ year $)=-0,06 x$ (year - first year $)+0.41$ & 0.06 \\
\hline 4 & October - December & $f($ year $)=-0,03 \times$ (year - first year $)-0.81$ & 0.03 \\
\hline III & \multicolumn{3}{|l|}{ 6 Monthly SPI } \\
\hline 1 & January - June & $f($ year $)=-0,03 \times$ (year - first year) -0.49 & 0.03 \\
\hline 2 & July - December & $f($ year $)=-0,06 x$ (year - first year) -0.16 & 0.06 \\
\hline IV & \multicolumn{3}{|l|}{9 Monthly SPI } \\
\hline 1 & January - September & $f($ year $)=-0,04 x$ (year - first year) -0.50 & 0.04 \\
\hline $\mathbf{V}$ & \multicolumn{3}{|l|}{12 Monthly SPI } \\
\hline 1 & January - December & $f($ year $)=-0,03 \times$ (year - first year) -0.58 & 0.03 \\
\hline
\end{tabular}

Table. 6. The Result of Sen's Projection

\begin{tabular}{|c|c|c|c|c|c|c|c|}
\hline Num & SPI Periods & \multicolumn{6}{|c|}{ Projection } \\
\hline I & 1 Monthy SP & 2020 & $\overline{D L}$ & 2030 & DL & 2080 & DL \\
\hline 1 & January & -0.37 & $\mathrm{NN}$ & -0.77 & $\mathrm{NN}$ & -1.58 & SD \\
\hline 2 & February & -0.86 & $\mathrm{NN}$ & -1.03 & $\mathrm{MD}$ & -1.36 & MD \\
\hline 3 & March & -0.48 & $\mathrm{NN}$ & -0.9 & $\mathrm{~N}$ & -1.73 & $S D$ \\
\hline 4 & April & -0.24 & $\mathrm{NN}$ & -0.67 & $\mathrm{~N}$ & -1.54 & $S D$ \\
\hline 5 & May & -0.28 & $\mathrm{NN}$ & -0.52 & $\mathrm{~N}$ & -0.99 & $\mathrm{~N}$ \\
\hline 6 & June & -0.63 & $\mathrm{NN}$ & -0.51 & $\mathrm{NW}$ & -0.26 & $\mathrm{~N}$ \\
\hline 7 & July & -1.43 & $\mathrm{MD}$ & -223 & ED & -3.83 & ED \\
\hline 8 & Angust & -0.20 & $\mathrm{NN}$ & -0.3 & $\mathrm{~N}$ & -0.51 & $\mathrm{~N}$ \\
\hline 9 & September & -0.41 & $\mathrm{NN}$ & -0.73 & $\mathrm{~N}$ & -1.38 & $\mathrm{MD}$ \\
\hline 10 & October & -0.85 & $\mathrm{NN}$ & -1.4 & $\mathrm{MD}$ & -2.51 & ED \\
\hline 11 & November & -0.16 & $\mathrm{NN}$ & -0.25 & $\mathrm{~N}$ & -0.43 & $\mathrm{~N}$ \\
\hline 12 & December & 0.81 & $\mathrm{NN}$ & 126 & $\mathrm{MW}$ & 2.17 & ED \\
\hline II & \multicolumn{7}{|l|}{3 Monthy SPI } \\
\hline 1 & January-March & -0.32 & $\mathrm{NN}$ & -0.61 & $\mathrm{NW}$ & -1.19 & $\mathrm{MD}$ \\
\hline 2 & April - June & -1.25 & $\mathrm{MD}$ & -2.05 & ED & -3.65 & ED \\
\hline 3 & July-September & -1.01 & $\mathrm{MD}$ & -1.32 & $\mathrm{MD}$ & -1.94 & SD \\
\hline 4 & October - December & -1.17 & $\mathrm{MD}$ & -1.76 & SD & -2.93 & ED \\
\hline III & \multicolumn{7}{|l|}{ 6 Monthk SPI } \\
\hline 1 & January - June & -1.25 & $\mathrm{MD}$ & -1.34 & $\mathrm{MD}$ & -2.1 & ED \\
\hline 2 & July-December & -1.71 & $\mathrm{SD}$ & -229 & ED & -3.44 & ED \\
\hline IV & \multicolumn{7}{|l|}{9 Monthy SPI } \\
\hline 1 & January - September & -1.49 & $\mathrm{MD}$ & -1.86 & SD & -2.6 & ED \\
\hline $\mathbf{V}$ & \multicolumn{7}{|l|}{12 Monthly SPI } \\
\hline 1 & January - December & -1.41 & $\mathrm{MD}$ & -1.71 & SD & -2.32 & ED \\
\hline
\end{tabular}


Based on projected results for SPI drought index values in the table above, at year 2020 for one monthly SPI the condition are relatively normal except in July which will have dry conditions. 3monthly SPI relatively dry except during the period from January to March. For SPI 6-monthly, 9 monthly and 12-monthly dry conditions expected to occur by the worst drought in SPI 6-monthly period from July to December.

The projection SPI drought index value in 2030 for SPI 1 monthly, relatively in a normal condition, in July and October will experience dry conditions and tends to damp in December. At the 3-monthly SPI, its will experience dry conditions and extremely dry, and normal occur in the period from January to March. For SPI 6-monthly, 9 monthly and 12 monthly will experience very dry conditions with the worst drought in the 6-monthly period in July-December.

The projection in year 2050 for SPI 1 Monthly, the conditions are relatively dry with the worst drought in July, while in December there will be conditions of extremely wet, for a period of 3 months, 6 months, 9 months and 12 monthly predicted will have extremely dry with the worst drought in SPI 3-month period from April to June with an index value of -3.65 .

Projections drought index for Bangga Watershed generally the graphed decreased so that the value of a drought index also decreased and the conditions become dry and extremely dry, except in SPI 1 monthly period in June and in December increased indicating that during this period the value of the index rose and conditions turn out to be normal or wet. When projecting a drought index is applied to Watershed else, then decline and the increase can be changed according to the drought index calculation and projection of the index value Watershed.

\section{CONCLUSION}

From the analysis of drought index with the SPI (Standardized Precipitation Index) method obtained the following results:

1. Rainfall Patterns in Bangga Watershed using the average rainfall for 1 month, 3 months 6 months, 9 months and 12 months proportional to the value of the SPI drought index for 1 month, 3 months, 6 months, 9 months and 12 months. When the rainfall is high then the value of the index shows the value of wetness, and even if the low rainfall deficit, then the value of a drought index also showed extreme dry conditions and dry.

2. In the period of 1-monthly SPI, the index value indicates relatively normal conditions, but there are a few years that show moderately dry and severely dry conditions in every month. At the 3-monthly
SPI, dry conditions occurred in some years such as in year 1993 and year 2013 with an index value of 1712 and -2192. At SPI 6-monthly, the index value indicates dry conditions in eight years with the worst drought index of -3254 . At SPI period of 9 monthly, a drought index indicates dry conditions in nine years SPI data with the worst drought index value of -3113 . In the period 12 months, dry conditions occurred in the 10 years of data SPI with the worst index value of -2922 .

3. In the SPI 1-monthly, the index value for the most severe drought conditions in the Bangga watershed was in April 2015 with an index value of -3516 (Extremely dry). In the SPI value of 3monthly period, the index value for the drought conditions are most severe in the period April to June 2015 with a score of -2815 (extremely dry). The SPI values for 6-monthly period, the index value for the drought conditions are most severe in the period from January to June 2015 with the index value -3254 (extremely dry). The value of SPI period of 9 months, the index value for the most severe drought conditions was in 2015 with a score of -2171 (extremely dry). In the 12-month SPI values, the value of the index is the worst hit in year 2015 with a score of -2922 (extremely dry).

4. From the projected drought level for Bangga Watershed in year 2020 and year 2030 in general watershed conditions are relatively normal for 1 monthly SPI. Dry conditions will occur on the 3, 6, 9 and 12 months SPI. In year 2050 general Bangga Watershed will experience extreme dry conditions with the worst drought on SPI 1-monthly in July

\section{ACKNOWLEDGEMENTS}

The author would like to thank Sulawesi III River Basin Organization which has provided data on hydrology to support this research.

\section{REFERENCES}

[1]. Sholikhati,I., Harisuseno, D. and Suhartanto, E. 2012. Hydrological Drought Index Identification study on Watershed based on Geographic Information System (GIS). University of Brawijaya. Malang

[2]. Mujtahiddin, M.I. 2014. Spatial Analysis Drought Index in Indramayu District. Journals. Geophysics Station. Meteorology dan Geophysic journal vol. 15 No.2, 2014 : 99 -107. Bandung

[3]. Pratama, A., Suhartanto E and Harisuseno, D. 2014. Analysis of Drought using Theory of Run Methods on Ngrowo Sub Watershed. Faculty of Mechanical Engineering Departmeny of Irrigation. University of Brawijaya. Malang 
[4]. Umami, F.N., Harisuseno, D and Suhartanto,E. 2014. Application of Geographic Information System for Drought Analysis using Deciles Method on Widas Watershed Nganjuk. University of Brawijaya. Malang

[5]. Jannah, N., Harisuseno D and Chandrasasi,D. 2015. Implementation of Palmer Drought Severity Index (PDSI) Methods for drought Analysis on Slahung subwatershed Ponorogo. Department of water engineering, faculty of Engineering, University of Brawijaya, Malang.

[6]. Utami, D., Hadiani. R.R and Susilowati.2013. Drought Prediction Based Standardized Precipitation Index (SPI) on Keduang Watershed in Wonogiri. E-Journal Civil engineering Matrix:221 -226. Sebelas Maret University. Surakarta.

[7]. World Meteorogical Organization. 2012. Standardized Precipitation Index User Guide. World Meteorological Organization, Switzerland.

[8]. Dwinasli,Y.A.,2015,Analysis of Drought and Wettnes in Miu Watershed with Standardized Precipitation Index Methods, Tadulako University, Palu

[9]. Indarto, Soesanto B and Diniardi, E.M, 2012, Detection of Rainfall Data Trend in East Java Using Mann - Kendall Test.National Seminar Papers. Faculty of Agricultural Technology. University of Jember.

[10]. Sutapa, I Wayan. 2014. Application Model Mann - Kendall and Sen's (Makesens) to detect Climate Change. Tadulako University. Palu 